\title{
Finding the real warriors: The case of rainforestation program adopters in Pilar, Camotes, Cebu
}

Labastida-Martinez, Seregena Ruth $₫$

Visayas State University, Philippines (seregenaruth@yahoo.com)

Fernandez, Guiraldo Jr. C.

Visayas State University, Philippines (guiraldo.fernandez@vsu.edu.ph)

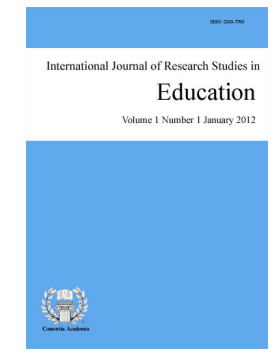

ISSN: $2243-7703$ Online ISSN: 2243-7711

OPEN ACCESS

\section{Abstract}

This qualitative research sought to identify the challenges and problems encountered by two individual adopters in their journey to protect and conserve the island of Pilar, Camotes. More specifically, it attempted to describe the personal attributes of the adopters who are teachers by profession as they lead in the implementation of environmental programs in the schools where they are teaching and on the island of Pilar, Camotes in general. The data were gathered from in-depth interviews with these two key informants who dauntlessly undertook the enormous challenge of educating the students and residents in Pilar, Camotes about environmental awareness and programs aimed at saving the island's terrestrial resource from degradation. Given their years of experience and service with the National Greening Program (NGP), the two respondents had sufficiently provided crucial information relative to Boddy's (2016) and Eisenhart and Borko's (1993) requirements for sample size for qualitative research. Results showed that many residents and students as well still exhibited negative attitudes towards environmental efforts. However, this pessimism is but the symptom of a much bigger problem which, based on the data gathered, is rooted in poverty. This problem surfaced as one of the biggest challenges that the adopters have encountered. However, despite this and many other difficulties encountered in the implementation of environmental programs, the adopters revealed that it is their sheer dedication and love for the environment that have kept their courage intact. Devoid of this genuine concern for Mother Earth and for the future residents of the island, they could easily succumb into the trap of lethargy, worse, apathy. If this happens, it will mean the end of Mother Earth.

Keywords: warriors; adopters; environment; Pilar; school 


\section{Finding the real warriors: The case of rainforestation program adopters in Pilar, Camotes, Cebu}

\section{Introduction}

Over the years, challenges brought about by the changing times have made teachers dynamic innovators of teaching approaches, strategies, materials and the like. They make themselves relevant by constantly honing their knowledge, skills and abilities in various ways and avenues possible. They conduct research and use its findings to reinvent the educational landscape so that learning will always be responsive to the diverse needs of $21^{\text {st }}$ century learners. Moreover, the turn of the century presents compelling societal needs for teachers to expand their realm of influence outside the confines of the classroom. Educating the youth is already a great contribution to society. However, given the worsening condition of the world's environment, transforming students into environmental stewards will propel the impact of education to greater heights.

Change drives advancement in technology; technology fuels growth and development. This progress equation, however, does not show the collateral damage to a country's natural resource. Anybody need not be environmentally inclined to see chemical wastes and pollution destroying nature on a massive scale and horrendous pace. According to Easton (2014), it is becoming clear that environmental problems do not respect borders. Using simple and easy to comprehend scenarios, he elucidated a rather complex process in this manner: smoke blows with the wind, carrying the locality's contamination to others; water flows to the sea, carrying sewage with it; birds migrate, carrying with them whatever toxins they have absorbed with their food (Easton, 2014). Alarmingly, this simple fact depicts how vulnerable to destruction the world's natural resources are. In the country, for instance, flooding can be a tell-tale sign of garbage-clogged river system or abused or bald forests. An environment champion and crusader for its sustainable development, Senator Legarda (2011) lamented over the way people are treating nature, polluting the air to alarming levels, thus exposing themselves to respiratory and pulmonary diseases; using up and, worse, dirtying the rivers which she calls as the source of life. All these draw the unmistakable truth: there is an urgent need to curb environmental distress which will happen only if people unite.

In the sector of education, teachers have responded to the challenge by reconsidering their roles in the academic milieu, that is, finding their purpose and meaning in the profession. Integrating simple, but habit-forming environmental concepts such as proper garbage disposal, segregation, recycling, gardening, to mention a few, will certainly create a lifelong impact that students can bring with them even as they leave academe. Teachers can maximize their close proximity with students by harnessing the best potential that this young human resource can offer. Most importantly, engaging students in the global drive to protect the environment, not only converges the wisdom of the old and the dynamism of the youth, but also ensures that efforts will be carried on. There will be perpetuators to sustain the crucial mission of saving the most amazing habitat that has nourished humanity since time immemorial.

This is no easy task for teachers. But their great skill at multi-tasking stimulates their dynamism to wrestle their way around to perform other responsibilities that demand their attention beyond classrooms and beyond office hours. In other words, a true educator possesses passion to do the things that matter, not only for one's self but for the greater majority; not only for today's generation, but for the generations to come. Simply put, there is so much that the education sector can do for a rapidly changing society, especially when the planet it considers a home is in constant threat of destruction.

\subsection{Statement of the problem}

The main purpose of this study was to probe into the challenges encountered by the teachers in the conduct 
Finding the real warriors: The case of rainforestation program adopters in Pilar, Camotes, Cebu

of rainforestation projects aimed at conserving the terrestrial environment on the island of Pilar, Camotes, Cebu. More specifically, it sought to identify the environmental programs done at school and in the community; find out the challenges encountered in the implementation of these environmental programs; determine the interventions implemented to address such problems; and, ascertain the personal qualities of the teachers that emerged as a result of problems encountered.

\subsection{Significance of the study}

Programs geared toward environmental conservation are very timely nowadays, and teachers who accept the task to lead are rare. However, once they accept the responsibility, they dedicate their lives in teaching students how to save and protect the environment. They contribute much in trying to save humanity from the hazards brought about by climate change and ensure that the youth will be able to emulate from them values that are crucial to address environmental problems. Yet this contribution often goes unnoticed. There is a dearth of materials that analyze and describe the important qualities exhibited by ordinary teachers but are fierce advocates of environmental conservation. Thus, this study humbly probes into the travails that they encounter as they face various hardships and challenges. In doing so, essential environmental conservation practices can be streamlined, environmental programs can be assessed and reinvented, and ideal practices promoted and replicated. Most importantly, efforts of these modern-day environmental champions can be documented to serve as inspiration and to challenge others to look at their immediate surrounding through the lens of one who wants to give back for the bounty enjoyed from Mother Nature.

\section{Methodology}

First, the component leader of the study complied with the necessary ethical requirements so that members of the team could conduct the interview. Then, the mayor of the island of Pilar, who himself is an environmental advocate, provided his all- out support by mobilizing his local officials to help the team in whatever way they could like showing the way around the island. Next, when key informants (KIs) had been identified, the project leader made the necessary arrangements in order to facilitate the scheduling of interviews and demo-farm visits.

For this qualitative study, the researchers relied on in-depth interviews with the two (2) KIs to gather the needed data. These key informants were Mr. Romeo Gutang and Mr. William Cabonegro. Mr. Gutang is an elementary teacher and is the district coordinator of the National Greening Program (NGP). Mr. Cabonegro, on the other hand, is a secondary school teacher and is the focal person of NGP. Both are frontliners in environmental conservation efforts in Pilar, Camotes, Philippines.

These two (2) respondents were deemed highly credible sources of information, given the nature of the problems identified in this study. Furthermore, the respective positions that they occupy with NGP on the island, their track record as environmental advocates, and their length of service with the program made them very competent sources for the kind of information sought. Having two (2) respondents in this qualitative study anchored its strength on Boddy's (2016) published article that explained the sample size for qualitative research. According to him, the determination of sample size is contextual and partially dependent upon the scientific paradigm under which the investigation is taking place. He further averred that sample sizes involving one single case can be highly informative and meaningful as demonstrated in examples from management and medical research (Boddy, 2016). This similar concept is echoed even back then by Eisenhart and Borko (1993) in their assessment of Nespor and Baralyske's article which also considered the narrative discourse of only two teacher respondents. Using accepted standards, Eisenhart and Borko (1993) came up with the conclusion that the study is a nice illustration of strong, credible and useful research that does not require large amounts of money, long periods of time, or highly sophisticated procedures (Eisenhart \& Borko, 1993).

Data collection procedure started at once. Permission was sought to record the interviews. Then, the recorded data were transcribed and analyzed. Although time-consuming, the in-depth interview proved very 
effective in gathering essential information, especially that this study is qualitative. This method allowed the researchers flexibility (e.g. rephrasing questions) and ask follow-up questions or to probe, particularly when necessary. The researchers had also obtained the consent to use full names of persons and schools that appeared in this article. Lastly, this paper is an offshoot of a bigger rainforestation program and research study conducted on the island by the academe where the researchers are presently connected.

\section{Discussion of results}

\subsection{Invigorating environmental programs: The intermarriage of new and traditional ways}

Lasang sa eskuylahan (School in a forest) - Vacant lots within school premises are utilized by planting different species of native trees (narra, magtalisay, molave) and fruit trees (jackfruit and tamarind). Spearheaded by the adopters, a combined force of school principals, teachers and parents engaged the very young elementary pupils (Grades 4, 5, \& 6) and high school students (Grade 8) to plant trees and take care of these trees by watering them regularly until they are big enough to survive on their own. Presently, the trees are growing, providing them shade, fresh air and an environmental niche where they can gather to do school activities/group studies or simply enjoy with friends to while away time while waiting for their next class. "Re-creating" a forest in their schools with their young, bare hands sends a very powerful message of nurture and stewardship among the young learners.

Environmental literacy programs - To realize the school-based tree growing project, seminar-workshops and trainings are conducted annually. School coordinators of the National Greening Program (NGP) in Pilar, Camotes gather regularly at the Pilar Central School (PCS) to discuss, acquire, share new technologies on how to grow trees and to disseminate new information and learnings back in their respective schools upon return.

Aside from this annual gathering, the adopters integrate environmental concepts in their class discussion. The subject called Technology and Livelihood Education (TLE), which is part of the curriculum for Grade 7 (first year high school) and Grade 8 (second year), becomes the venue thru which students are exposed to concepts on environmental awareness and conservation. In 2008, the Pilar National High School (PNHS) received a Certificate of Recognition for its "successful and sustained implementation of the Greening With our Environment Now (GWEN)" program from the governor of Cebu Province.

Environmental clean-up drive - Twice a year, Grades 5 and 6 pupils conduct coastal cleanup to remove the plastic and other pollutants that are destroying the mangroves and shorelines. But for the older (high school) students (Grades 7 to 12), the cleanup is done every last Saturday of the month. This activity is properly mapped out in such manner that students are distributed all throughout the different places of the community (parks, schools, highways) and in planting sites (Sitio Clara, San Juan, Brgy. Esperanza) in Pilar, with the approval of the PNHS principal, Mr. Ricardo Borinaga, who is also an environmental advocate himself.

Interestingly, parents and other stakeholders, inspired by the environmental efforts exerted by their children, usually volunteer their services too. Reportedly, this school-based activity most often ends up in a communal effort among the Pilaranons to save and protect their island. According to the adopters, this activity usually gives them a sense of fulfillment, being able to lead the community and gain the trust and confidence of the people.

Demo-farms on rainforestation biome and biodiversity restoration - The tree growing activities on the island have been guided by the concepts of biodiversity. Several varieties or species of trees have been planted, namely: lauan, narra, magtalisay, kalumpit, tugas, kamagong, and fruit-bearing trees too like jackfruit, santol, guava, etc. These activities are done both in schools and in the community. At schools, children as young as those enrolled in Grades 5 and 6 for the elementary level, and Grades 7 to 12 for junior and middle school have already demonstrated their concern for the environment by planting trees. The adopters bring their students to their planting sites in Brgys. Dapdap and Esperanza, and Sitios Clara and San Juan, Pilar, Cebu. When this 
activity started in May 2013, students would go to the planting sites twice a month for the first three years, then eventually decreasing it to monthly visits for maintenance activities like cleaning the areas, cultivating the soil and removal of weeds. The adopters, however, would visit the sites daily and even work there on weekends.

At the community level, the adopters would also organize tree planting activities, collaborating with the barangay captains. They would even go to the extent of conducting house to house campaigns to remind the residents regarding the scheduled tree planting. Fortunately, they have a very supportive mayor who is an environment advocate himself, thus tree planting activities are facilitated. Other than the demo-farms where the adopters have forged a memorandum of agreement with private lot owners, the adopters have expanded their environmental projects through the agreement entered by the Local Government Unit (LGU) in Pilar with the Ramon Aboitiz Foundation, Inc.

\section{Table 1}

Environmental programs conducted in Pilar, Camotes, Cebu

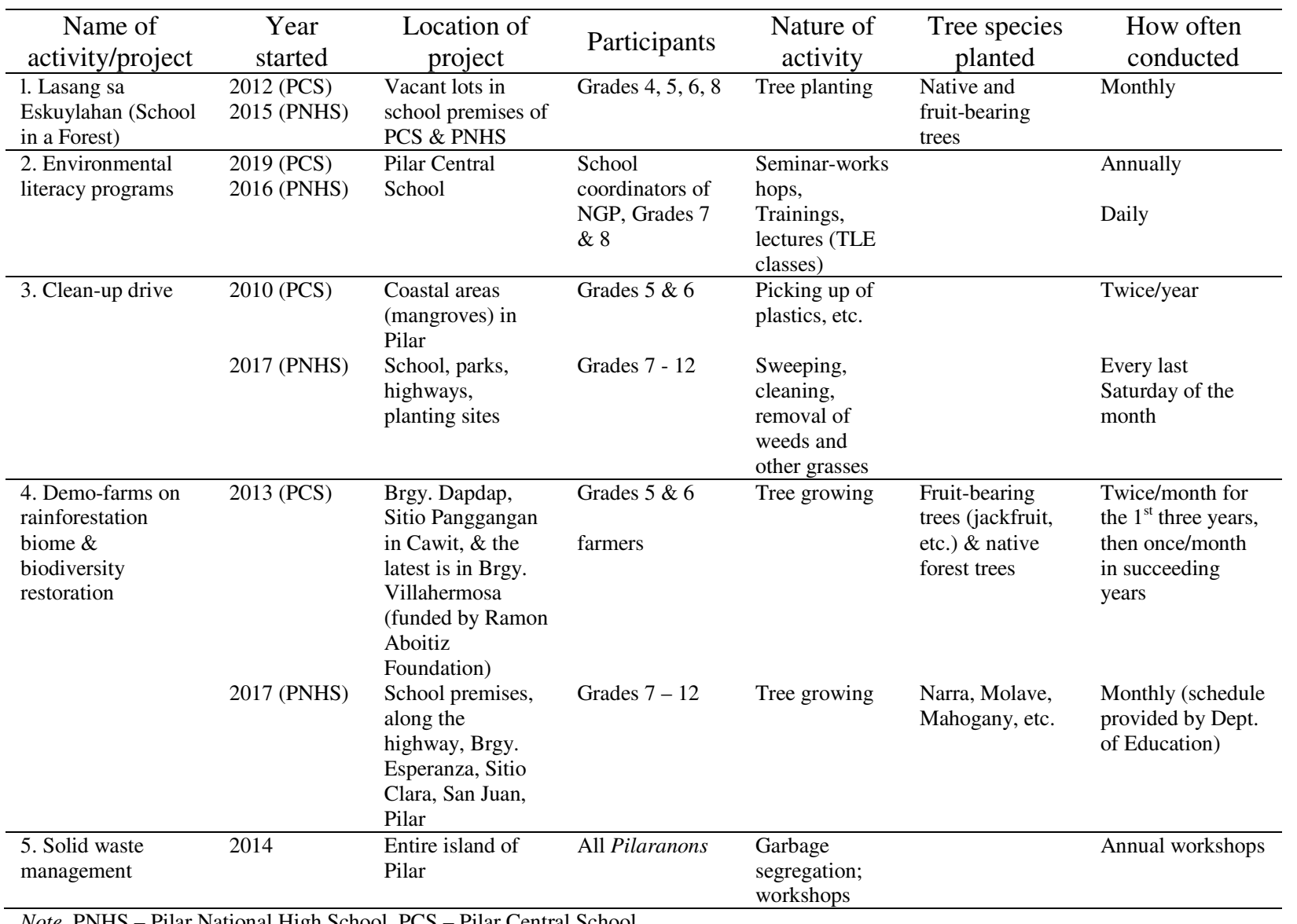

Note. PNHS - Pilar National High School, PCS - Pilar Central School.

Solid waste management - Generally speaking, the Pilaranons always demonstrate their love and concern for the island through their active participation in synchronized community cleanliness drives and cleanups organized by the LGU. This collective effort becomes very evident, especially during monsoons when volumes of floating garbage are washed ashore, dirtying the coastlines and polluting the mangroves of the island. As a community surrounded by waters, the Pilaranons gather and help each other in collecting the garbage and segregating these so that the plastic and other nonbiodegradable wastes are separated from the biodegradable ones. Thus, the spirit of Bayanihan is very much alive among them. Practically speaking, the Pilaranons are aware on how to handle their garbage because they (teachers, students, school children, parents) must attend seminar-workshops held annually on the island. These workshops are conducted by experts in the field such as foreign peace corps and representatives from the education sector where the adopters are affiliated. 
There is even a joke that Mr. Gutang shares with students during workshops. He tells students that in segregation, they need three (3) containers - one for the dry waste, another for the wet waste, and still another for the "confused", referring to students who continue to throw their garbage indiscriminately. Interestingly, Mrs. Rosely Merino, the school guidance counsellor, has suggested an innovative and purposeful strategy on how to deal with this - to require their students to make an eco-brick from the garbage collected. These echo bricks were used in the construction of concrete benches in the school, replacing the hollow blocks. Now, the students have not only cleaned their surroundings, but have also contributed the material that has provided them a place to sit and relax during their free time.

\section{Challenges encountered}

Any undertaking done for a good cause is beset by challenges. The benefits that the community will gain from it does not exempt it from problems. On a more positive note, these challenges, though may be very difficult to overcome at times, will prove the strength and determination of those who take on the leadership to make things happen. The discussion following tackles the school and community-related challenges encountered by the adopters, the interventions they employed to address said concerns and their personal qualities that manifest as they faced the problems head-on.

\subsection{School-related problems}

Lack of concern for the newly-planted trees. Since water is scarce on the island, the adopters require students to bring water from home. However, they echoed their observation that some students tend to neglect the trees after these were planted. They were saddened that many students shun from the simple task of watering the plants or not coming back to check on the plants. Obviously, the students were not able to sustain their enthusiasm demonstrated during tree planting. As a result, it is the adopters themselves who would water the plants, otherwise these would wither and eventually die under the sweltering heat of island sun. The adopters feel strongly that there is still a need to inculcate compassion for the trees among students. Without it, the purpose of the tree planting activity would be defeated.

Mischievousness. Tree guards serve to protect young trees from wandering farm animals. These wooden or bamboo fences are deliberately placed around the growing plants so that they will not be eaten by animals. Mr. Gutang sadly narrated that they would occasionally find tree guards destroyed and their debris scattered in the middle of the road, as if to demonstrate defiance. At first, they had no idea who the culprits were, but eventually, the residents living nearby had informed them having seen male students doing it. Reportedly, the students appeared to be drunk, and would usually do the misdeed at nighttime, especially after school programs. The teachers had speculated that this was the group of students who did not like the tree planting activities enforced by the school and, therefore, expressed their dislike in that manner, or, perhaps such was simply a case of being naughty. On hindsight, the teachers shared their frustration, realizing that the younger generation still failed to understand the crucial role of trees in environmental conservation.

Indiscriminate throwing of trash. Many students are fond of eating junk foods, as shown by the garbage scattered on the park they frequented. Throwing of wrappers and other plastics used to wrap food or snack items continues to be a pervasive practice among the students. Mr. Cabonegro conveyed the frustration of the school principal, Mr. Borinaga, who observed that despite seminars, lectures and other environment-oriented activities that their students had been exposed to, many of them still did not practice what they had been taught. Proper garbage disposal may be simple, yet it has serious repercussions to the environment. Sounding almost defeated, he alluded to one of their biggest struggles encountered - changing the mindset of the new generation:

"Ang mentality pod usahay aning mga bata karong panahuna." (The mentality of our students nowadays is different.)

The implication being that throwing garbage such as plastic wrappers seems like second nature to most students

72 Consortia Academia Publishing (A partner of Network of Professional Researchers and Educators) 
in this generation, and therefore may take some time to correct.

Poor attendance in monthly activities. The adopters have calendared monthly activities such as tree planting, farm visits, etc. But the participation of some teachers and students is disheartening. In the absence of role models to emulate, students can be likened to a wandering flock. Mr. Cabonegro noted:

“E.announce pa jud, pero kanang uban, magpabungol-bungol kay wa pa jud siguro makatuhop ang ilang paghigugma sa mga kahoy ... nga importante ang kahoy.” (Activities are announced, but some students pretend not to hear. This indicates that they have not yet fully developed their love for trees ... they have not yet fully grasped the importance of trees.)

On a positive note, the focal person likewise reported that they also have a good number of students who are very responsible and comply enthusiastically with the tree planting tasks and other activities as well.

Poor participation of some teachers in environmental activities. Mr. Gutang believed that teaching students purposively and meaningfully about conservation entails the holistic participation of all stakeholders, and teachers should be at the frontline. However, he disclosed that there is a seemingly lukewarm behavior demonstrated by some teachers. Mr. Gutang said:

Dili ang mga bata ang problema kay ang mga bata under man sa teachers. Sila jud ang mo drive sa mga bata nga mao ni ang buhaton. So, siguro, on the part of the teachers, kuwang sila og love sa nature. Usa jud na sa ako nakita. (For me, the problem is not the students but the teachers. The students are only under their tutelage. It is the teachers who must show how to care for the environment properly, and drive students to do the same. I can say that the teachers' love for nature is still lacking.)

This observation was echoed by the principal of Pilar National High School (PNHS). According to Mr. Cabonegro, the principal was disheartened by the fact that other schools in Camotes were remiss in ensuring that environmental programs are done as scheduled and planned. He noticed that it is only PNHS that has been working towards achieving the goals of the NGP.

Absence of a dedicated school coordinator. Mr. Cabonegro pointed out that a major drawback encountered is the absence of a dedicated coordinator, willing to serve long enough to ensure consistent and effective implementation of programs. It has been observed that the sitting coordinators in other schools would give up the assignment as soon as there are newly-hired teachers to take over the place. Apparently, new teachers are more likely just "forced" to accept the assignment because they have no "voice" to say "No". Mr. Cabonegro opined that:

“... di jud diay ganahan sa assignment. Wala pa nila makita ang long-term benefits.” (They do not really like the assignment. They have not realized the long-term benefits of the greening program.)

Such a case is counterproductive to the goals of the NGP. He believes that constantly changing its coordinator is not good, since program implementation would have no continuity.

"Mao na nga dili ma-implement og sakto ang programa." (That is why the program cannot be implemented properly.)

But what is more upsetting to the adopters is the fact that without commitment, the program would eventually result in failure. As human beings, they know that they can only do so much. If others are not serious in going about the tasks of environmental conservation, how can Mother Earth survive in ten, 20 or more years? Faced with this stark reality, these hard-core warriors for the environment heaved a deep sigh, knowing they cannot win this fight alone. 


\subsection{Community-related problems}

Cruelty towards plants. The adopters find it difficult to understand why some residents cannot be kind to plants. Mr. Gutang narrated how his heart dropped each time he visited his demo-farms to find once luxuriant growing trees droop to the ground. He is angry because this does not happen only once. Young trees were either bent down, crushed or uprooted for no apparent reason. Unfortunately, these farms are far from home, and keeping watch all day long seemed impossible due to work and family. He said that some people seemed to enjoy seeing trees die:

"Balion ang sanga, tamakan ang tanum nga naghirig, Ila jud tuyuon kay samok sa agianan ug tugwayan sa ilang mga binuhing mananap. Sayang kaayo kay taas na ang tanum, nabali lang.” (They would break stems and branches, complaining that these had blocked their way or trail. Others would graze their farm animals which would feast on the young leaves.)

Based on the adopter's narrative, the foregoing was a recurring problem in his demo-farms. The residents' attendance to environmental conservation campaigns had not changed their distorted personal views.

Socio-Economic Factor. Poverty is the biggest problem that has confronted the adopters. The barangay ordinance that prohibits, for instance, the pasturing of animals in cultivated farms cannot be strictly implemented. Mr. Gutang and Mr. Cabonegro pondered that, at times, they can be overly considerate because they are overtaken by pity. The socio-economic status of most violators plummets way below the poverty line. The farmers' need to survive is more defined than the need to take care of trees or environment.

With most of them being very poor, the residents need to secure, first of all, their food for the day. This daily struggle is known to the adopters. As a result, the adopters and other authorities in the barangay handle offenses with the utmost humane consideration. Others have accused them of being lenient or having no political will, but for the adopters, it is a matter of judgment call that they are compelled to do for their fellow human beings. Mr. Gutang admitted:

"Walay ngipon ang ordinance. Mga pobre man lagi kaayo... mao e.settle nalang." (The ordinance cannot be implemented because the violators are very poor. Thus, violations are just settled.")

The adopter said that they are dealing with lowly tenants who make a living by herding cows or goats for rich families. Mr. Gutang recalled a heart-rending story where it was a DENR official who caught a herder. The damage of the crops was huge (P30,000.00), and the tenant could obviously not pay the fine. He went into hiding, leaving the island and his family behind. Being the breadwinner, who would provide for his family now? Deprived with a father, would there be food for the children? The adopter struggled with these thoughts for a long time.

Similarly, Mr. Gutang confided that the poor farmers he had talked to were sometimes victims of exploitation. According to narratives, not all who came to the island and called themselves environmentalists fulfilled their promise to help farmers earn a living by planting trees. As observed by the adopters, the prospect of earning from a decent work was met with great enthusiasm. Unfortunately, however, the promised compensation never came. As of this writing, the economic benefit has not reached the poor farmers and will never be. Poverty has made them vulnerable to manipulations. Mr. Gutang surmised that this could explain why some of them have developed some doubts, misconceptions, and worse, resentment.

Poverty is ubiquitous. It is reported as one of the four major reasons why the world has environmental problems. According to Miller et al. (2013), the daily lives of the world's poorest people are focused on getting enough food, among others, and in the process some of them destroy potentially renewable forests. They observed that this group is desperate for short-term survival, and does not have the luxury of worrying about

74 Consortia Academia Publishing (A partner of Network of Professional Researchers and Educators) 
long-term environmental quality or sustainability.

Insufficient Information Campaign. Based on interviews, one possible reason that surfaced to explain why many residents are habitual violators of ordinances is the likelihood that they have not fully understood these ordinances. As Mr. Gutang admitted:

“Wa kaayo kasabot ang mga residente. Kuwang siguro sa pagpasabot." (They do no not understand because we have not explained fully.)

The lack of comprehension could stem from many factors such as language barrier, the need to simplify complex terms, purpose of the farmer (Will they benefit from it or not?), personal interest of the farmer (Is their participation voluntary or not?) and many more. Although the adopter could not figure out where exactly the problem lies, he claimed that there is a need to strengthen dissemination efforts so that the goals of the NGP can be achieved.

Stubbornness. Mr. Gutang and Mr. Cabonegro likewise observed that it is difficult to change the attitudes of the residents. According to them, many residents lack the genuine love and concern for trees and other plants. Mr. Gutang opined that since many habitual offenders are tenant-farmers themselves, he could not understand why they continue to act irresponsibly. He lamented:

“Gahi gyud og ulo, Ma'am.” (They are really hard-headed).

The adopter may be right. Logic dictates that since the farmer-tenants are already mature, then they ought to possess the discernment to decide for themselves what is right or wrong for their farms. On the other hand, since the farmers are usually older than the adopters, Mr. Gutang also feels that this situation makes it doubly challenging to change their perceptions.

Threat to adopter's life. This is the most serious challenge that Mr. Gutang had experienced. The island has herders who seem not to care about the life of thriving trees in the adopter's demo-farms. On one occasion, he saw cows grazing in his farm, and the herder had tied the animals' ropes around his growing narra trees so that the animals could not wander away. But this had almost uprooted the young trees. Fed up with this gross irresponsibility, he untied the animals which, unfortunately, headed straight to the herder's maize plantation, eating the succulent crops. The next day, the adopter found a number of his narra trees chopped and scattered on the ground conspicuously. According to Mr. Gutang, he understood the "message" well - it was a warning that he could be next.

His loved ones have worried over his safety, but the situation has not slowed him down. He admits taking measures to protect himself like leaving the farm early and varying his schedules of farm visits. Best of all, he prays a lot.

\section{Interventions employed to address problems identified}

\subsection{For school-related concerns}

Constant reminder. On the part of the students, the adopters have accepted that fact that students will always be students. Being young, they exhibit attitudes and actions that demonstrate their carefree and, perhaps, "rebellious" stage. As teachers, they understand early on that to deal with attitude problems, they have to "teach appropriate behavior rather than use punishment should inappropriate actions happen" (Habberman 1995, cited in Cruickshank 2009). Thus, the adopters believed that the best way to deal with the situation is to constantly remind students of their responsibility towards the environment and help them realize of their crucial role in environmental preservation. The adopters stress this during the school's conduct of seminars and lectures and in their TLE classes. 
Replacing tree guards. On the issue of students destroying the tree guards, the adopters admitted that they could not do anything about it. Although some residents living in the neighborhood had informed them that it was perpetrated by their own students, the residents could not pinpoint as to who exactly the students were, since the offense usually happened during nighttime. Thus, the adopters had no choice but to replace the destroyed tree guards by constructing new ones.

Regular clean-up drive. In terms of students' littering the park, the school principal has already enforced a directive for the regular cleanup of the place. Also, the students are constantly reminded to observe proper garbage disposal. Trash cans are likewise placed in the park to ensure the cleanliness of the place. Aside from this, the guidance counselor's suggestion to require all students to submit three (3) eco-bricks every quarter of each school year has also been put into practice.

Imposing fines/extra requirements. In terms of students' absences or poor attendance during tree planting activities, the PNHS principal had instructed the school coordinators of the NGP to check attendance of their students each time there was an activity of that sort. Students who demonstrated habitual absenteeism would face a corresponding "sanction", which usually included a requirement to plant a specific number of trees, or another activity which was decided and enforced by the school after final examinations, when students process their clearance.

Compulsory attendance in trainings/seminars. With regards to teachers' indifference towards environmental activities, the adopters initiated trainings conducted in their school district where teachers' participation was required. They invited competent speakers/trainers from academe and other national and international institutions in order to elucidate the teachers on the long term benefits of trees and to motivate them to do their part in the conservation efforts.

Narratives of personal experiences were also done. To inspire the younger teachers, Mr. Gutang said that he would often share with them how his active involvement with environmental projects had become instrumental in his promotion, from Teacher 3 (salary grade 13) to Master Teacher 1 (salary grade 18). However, he admits being prudent in telling his story so as not to create the impression that his motivation was prompted by monetary considerations. For him, the promotion was simply the bonus that was unexpected.

\subsection{For community-related concerns}

Adoption of a new strategy for environmental campaigns. In addition to trainings and seminars, the adopters plan to wage a massive information campaign for the townspeople. To reach a huge audience in a short span of time, the adopters said that they plan to hold said campaign after the celebration of Sunday mass in their parish. This strategy is something new and different. They will collaborate with the parish priest because he is a known supporter of environmental advocacies. As of this writing, the plan still needs fine tuning to ascertain its success when implemented such that it will be able to enjoin the full participation of the community and, importantly, will not arouse the antagonism of the already disadvantaged people.

The need to collaborate, especially with the local government unit (LGU). On the aspect of poor implementation of municipal/barangay ordinance, they are aware that a strong political will on the part of implementers is necessary. Although they admit that this problem is one of their biggest struggles, given the socio-economic status of most violators; nonetheless, they both agreed on imposing the barangay ordinance firmly so that lessons can be learned, and tenants will become responsible and conscientious herders. Mr. Gutang and Mr. Montenegro also agreed that steps be undertaken by the local government in order to assist displaced tenants. Providing them alternative employment or assistance, for instance, will possibly reduce the feeling of resentment, if not at all eradicate it. This will promote cooperation because the tenants will feel that the government is there to help them, not to punish them. In fact, fostering a healthy relationship between the LGU and the residents is always seen to bring about positive results. Reportedly, when a mayor launched the Eco-Brick Project to improve garbage management on the island, he adopted a very ingenious way of ensuring 
maximum participation of his constituents. He would exchange one eco-brick with one kilo of rice.

Inculcating the concept of stewardship. Overall, the adopters believe that empowering the residents, farmers and the students as well will do much in order to awaken their sense of responsibility toward the environment. When the people are empowered, they will take care of the environment on their own volition. This has always been stressed by resource persons/trainers from both private and public institutions who have assisted them, one of whom is Dr. Marlito Bande, director of the Institute of Tropical Ecology and Environmental Management (ITEEM) at Visayas State University (VSU), during trainings conducted on the island. In his talks, Dr. Bande would always emphasize the importance of ecological diversity and improving people's knowledge about the best practices that people can adopt to conserve the environment.

This is congruent with the empowering statement made by William K. Reilly (cited in Cunningham \& Cunningham, 2009) where he manifested his support to environmental literacy. According to Mr. Reilly, environmental literacy can help establish a stewardship ethic which he describes as a sense of duty to care for and manage wisely people's natural endowment and productive resources for the long haul. It is not enough, he says, "for a few scientists to know what is going on while the rest wander about in ignorance" (Reilly, cited in Cunningham \& Cunningham, 2009).

\subsection{Personal qualities of adopters}

As educators, the individual adopters might be naturally endowed with qualities that enabled them to deal with problems encountered. However, actual exposure and association with people with diverse personalities and complex backgrounds could be more demanding and challenging than anyone could imagine. Thus, analyzing the attributes that these two adopters possess is crucial in understanding the success or failure of environmental programs implemented on the island.

Well-informed. The two adopters attended and participated in a number of trainings and workshops on environmental issues, conservation and protection. They were eager learners of concepts and practices that make them deserving to be called stewards of Mother Earth. They partnered with and were mentored by local, national and even international organizations that honed their abilities and further heightened their advocacy to protect the environment. All these had transformed these two educators in Pilar, Camotes into empowered individuals ready to take on the colossal mission of saving the island from the brink of environmental collapse.

Broad-minded. Though the residents in the island are so diverse, their motivation in joining environmental programs generally stems from their personal interest to earn. If this need is not met, many of them would quit. Understandable. But what was more baffling to the adopters is the observation that many of the residents still manifest an uncaring attitude towards the trees and environment. This pervading attitude is like an acid test to the adopters' broadmindedness. But as always, they resign to the idea that people are naturally different from each other:

Lain-lain man jud ang tawo, Ma'am, ato lang silang sabton." (People are naturally different from each other. We just have to understand them.)

According to Matlin (1999), humans differ widely from one another; as a result, people often respond differently to the same stimulus situation. As other experts would put it, no two persons are alike. Grounded on this dictum, the adopters choose to understand, not run away from the challenge. From there, they try to find ways to patch up the differences so that plans can be achieved.

Persistent. One of the strongest qualities that the adopters possess is their persistence. Even if the residents, teachers and students as well have to be reminded constantly and repeatedly, the adopters have never given up hope. Had it not been for this attribute, the inhabitants of the island of Pilar, Camotes would not have seen treetops nor experienced the invigorating breeze. Although Mr. Gutang recalled that there were moments that 
they doubted if goals of the NGP could be realized, especially when the pressure weighed heavily on their shoulder or when they saw that their efforts did not seem to work:

"Bisan kapila na nimo balik-balikig pasabot, mao lang gihapon." (No matter how much we have repeatedly explained so that they will understand, they have not changed.)

Nonetheless, the noble task of preserving the environment is second nature for these adopters. Being humans, there might be situations when they wobbled momentarily, but always they go back to the fight like what good soldiers do and heed the call of protecting Mother Earth.

Given these circumstances, it is impressive how these two adopters manage to get by. The sight of trees swaying and increase in girth is enough to rouse them when spirits are low, and they are back on their feet again, raging campaigns against those who destroy the environment and its resources.

Hard-working. The demo-farms cultivated by the adopters are the living testimony of how industrious and dedicated they are. The once barren fields and parcels of land deplete with vegetation now grow diverse species of trees that have supplied not only precious water to the island, but also priceless shade for its residents. Further, since they are also teachers, they are relentless in their drive to conduct tree planting activities regularly in schools and neighboring areas. Not only that, they spearhead and support other environmental awareness programs and campaigns, for instance, the imposition of the ordinance that all couples applying for marriage license be required to plant trees. This practice has resulted in the formation of a "little forest" in the church's vicinity.

Passionate. Despite setbacks encountered, the two adopters continued to do what had to be done. Driven by the ultimate goal of saving the island's terrestrial resources, they headed steadfastly to that direction, no matter what the cost. Family concerns can be a source of pressure, especially when a spouse starts complaining about a partner's regular absence from home. This happened to one of the adopters. He was too engrossed with farm work, unaware that he had been spending more time in the farm than at home. Although he understood his wife, he could not just leave the growing trees to the care of natural rain that might not come at all. Realizing the futility of their quarrels, the wife gave up and allowed him to stay in his farm even on weekends. He was just so grateful that his wife had finally understood his passion and love for trees.

Sympathetic. The economic status of most farmers interferes with the implementation of environmental programs. The adopters find it difficult to impose fines or apprehend violators because of the latter's poverty. For humanitarian considerations, the adopters were often times left with no choice, but to forgive herders otherwise many children would have nothing to eat for a day and even longer, if families are fined or if fathers are locked up. Often, violations are just noted and settled amicably and violators make a promise not to repeat the wrong done. The adopters revealed:

\section{Pasayloon lang sila bisan kapila naka-violate kay lisod man pod lagi ang economic ... ang panginabuhi. (We have to forgive them despite repeated violations because)}

The trees are important; on the other hand, the adopters also understood the plight of their neighbors, that they were just trying to earn a living. Admittedly, the adopters said that the foregoing scenario demonstrates one of the most emotionally-draining realities that they have to grapple with every day in their advocacy.

Prudent and influential. Dealing with different kinds of people with different backgrounds is very challenging. The adopters believe that it needs "psychology" to be able to understand and deal with these people effectively. In his case, Mr. Gutang makes it a point to establish a smooth-interpersonal-relationship with people in the community. He befriends them and finds time to talk with them, first about simple things until conversations progresses to convincing them to join community activities and to help him watch his demo-farms. But this does come for free because the standbys would usually ask him for alcoholic drinks. Thus, over bottles of drinks (tagay-tagay), he begins to influence them. In the end, he achieves his purpose and ordinary people 
disperse feeling that they can contribute something.

His experiences have increased his knowledge about human nature. Smiling, he quipped that connecting with people is important in order to enjoin their cooperation, and educating them requires much patience and dedication as well as a little "budget" to make things happen.

Credible. The teachers are environmental leaders by example. At school and in the community, their names have become synonymous to environmental protection and conservation. Their work, program involvement and leadership skills speak volumes of their dynamism, dedication, love and concern for the environment, making them role-models of hard-core environmental warriors. They are at the forefront in teaching the youth and colleagues to plant trees, protect and care for nature. They are at the frontline in uniting communities when these are baffled and exploited. They are credible warriors for Mother Earth when it calls for protection, and the island has put its trust on them. Cruickshank et al. (2009) aver that credibility and trust must be earned and the best way to earn it is through a person's behavior. With what they have done and will continue to do for the island, they are able to demonstrate their credibility:

We have to inculcate love for the environment among our students because they are the future and hope of the island. Students must be taught how to appreciate the boundless benefits of trees to humankind.

They are the modern-day warriors the world has yet to know and discover. In a faraway island of Pilar, Camotes, their works and aspirations for a greener world thrive.

\section{Conclusion, implications, and recommendations}

\subsection{Conclusion}

The proactive environmental leadership demonstrated by the teachers make them modern-day warriors for Mother Earth. The myriad challenges encountered had not deterred them doing from achieving what they know must be done in order to save the terrestrial environment of the island. Instead, the difficulties have compacted their resolve to pursue crucial environmental projects, constantly reinventing strategies employed in order to compel the youth to be involved. Had it not been for their dedication and love for their environment, qualities that are hard to come by in this technology-driven generation, the island of Pilar, Camotes would have not spawned and sustained green canopies that have profusely outlined its lowlands and hills.

\subsection{Findings and implications}

The environmental projects spearheaded by the adopters have engaged students in simple, yet very doable and meaningful ways geared towards environmental conservation. This sends a strong message that anyone, regardless of age and personal circumstances, can contribute something for the environment. Aside from this, students have developed a strong sense of environmental awareness due to their involvement in the activities. More importantly, these activities have brought them closer to nature, emulating from their mentors empowering skills and values of environmental stewardship. Students must be trained early to care for the environment for these programs to succeed.

Challenges and problems are always present in any undertaking, no matter how beneficial to the community the programs may be. There will always be people or constituents who will fail to understand, for instance, policies implemented in their barangay. As demonstrated from the experiences of the adopters, passion and dedication are needed to sustain them in this kind of work in order to overcome the stumbling blocks along the way. Of course, political will is important for successful implementation of programs, but the use of compassion, at times, outweighs the enforcement of stringent rules to compel people to obey, especially for those who live below the poverty line. 
Collaboration among all sectors in the municipality is key to success. A very noticeable factor contributing to the success of rainforestation programs on the island is the fact that the schools are not left alone in conservation efforts. All sectors in the municipality - the LGU through the mayor, church, schools, Pilaranons, and researchers, scientists from national and international organizations as well as academe, all poured in their expertise, technology and resources in order to sustain the success of programs implemented.

\subsection{Recommendations}

Based on the findings, the following are propounded:

$>$ Undertakings of ordinary people doing extraordinary work for a worthy cause be documented in order to disseminate the best practices they have adopted in addressing the environmental issues encountered.

$>$ The efforts adopted to address communal concerns be assessed and improved based on community needs, then replicated in other communities to sustain environmental development on a broader or national scale.

> Studies that narrate and describe experiences encountered by adopters in solving communal environmental problems can serve as a useful guide or a relevant reference for other adopters to emulate when confronted by similar challenges and situations. Thus, studies advancing this genre be pursued and be given their rightful place in this science-technology oriented world.

Acknowledgement: We would like to thank Ms. Mary Rose Borinaga and Mr. Vimson Alastra for helping us complete the data collection in the midst of the pandemic. Thanks are also due to Mr. Alberto C. Martinez, Jr., and Christian for their dexterity in putting the final manuscript together and all VSU librarians for their warm assistance.

\section{References}

Boddy, C. R. (2016). Qualitative market research. https://doi.org/10.1108/QMR-06-2016-0053

Cruickshank, D. R., Jenkins, D. B., \& Metcalf, K. K. (2009). The act of teaching (5th ed.). New York: McGraw-Hill.

Cunningham, W. P., \& Cunningham, M. A. (2009). Principles of environmental science: Inquiry and applications (5th ed.). New York: McGraw-Hill Companies, Inc.

Easton, T. (2014). Taking sides: Clashing views on environmental issues (16th ed.). United States: McGraw-Hill Education.

Eisenhart, M., \& Borko, H. (1993). Designing classroom research: Themes, issues and struggles. Massachusetts: Allyn \& Bacon.

Legarda, L. (2011). Climate change message of our times. Excerpts from Senator Loren Legarda's speeches.

Malabon City: Libro ni Loren Foundation, Inc.

Matlin, M. W. (1999). Psychology (3rd ed.). USA: Harcourt Brace College Publishers.

Miller, T. G., Jr., \& Spoolman, S. E. (2012). Living in the environment (17th ed.). Canada: Brooks/Cole Cengage Learning International Edition. 